\title{
Food protein hydrolysates as a source of dipeptidyl peptidase IV inhibitory peptides for the management of type 2 diabetes
}

\author{
Orla Power ${ }^{1,2}$, A. B. Nongonierma ${ }^{1,2}$, P. Jakeman ${ }^{2,3}$ and R. J. FitzGerald ${ }^{1,2 *}$ \\ ${ }^{1}$ Department of Life Sciences, University of Limerick, Castletroy, Limerick, Ireland \\ ${ }^{2}$ Food for Health Ireland, University of Limerick, Castletroy, Limerick, Ireland \\ ${ }^{3}$ Human Science Research Unit, University of Limerick, Castletroy, Limerick, Ireland
}

\begin{abstract}
The prevalence of type 2 diabetes mellitus (T2DM) is increasing and it is estimated that by 2030 approximately 366 million people will be diagnosed with this condition. The use of dipeptidyl peptidase IV (DPP-IV) inhibitors is an emerging strategy for the treatment of T2DM. DPP-IV is a ubiquitous aminodipeptidase that cleaves incretins such as glucagon like peptide 1 (GLP-1) and glucose-dependent insulinotropic polypeptide (GIP), resulting in a loss in their insulinotropic activity. Synthetic DPP-IV drug inhibitors are being used to increase the half-life of the active GLP-1 and GIP. Dietary intervention is accepted as a key component in the prevention and management of T2DM. Therefore, identification of natural food protein-derived DPP-IV inhibitors is desirable. Peptides with DPP-IV inhibitory activity have been identified in a variety of food proteins. This review aims to provide an overview of food protein hydrolysates as a source of the DPP-IV inhibitory peptides with particular focus on milk proteins. In addition, the proposed modes of inhibition and structureactivity relationship of peptide inhibitors are discussed. Milk proteins and associated peptides also display insulinotropic activity and help regulate blood glucose in healthy and diabetic subjects. Therefore, milk protein derived peptide inhibitors may be a unique multifunctional peptide approach for the management of T2DM.
\end{abstract}

Dipeptidyl peptidase IV inhibition: Type 2 diabetes mellitus: Bioactive peptide: Glucagon like peptide-1: Glucose-dependent insulinotropic polypeptide: Milk protein: Hydrolysate: Functional foods

Type 2 diabetes mellitus (T2DM) is a chronic metabolic disorder that is characterised by impaired insulin secretion and insulin resistance. There is an increasing global burden of this disease and it is estimated that by 2030 approximately 366 million individuals worldwide will be diagnosed with T2DM ${ }^{(1)}$. T2DM is a complex disease and there are many co-morbidities and complications associated with it including obesity, hypertension, high cholesterol, CVD and renal failure ${ }^{(2)}$. Therefore, effective strategies to manage T2DM should not only address hyperglycaemia but also prevent further progression of the disease and its associated complications.

In recent years, novel strategies for the treatment of T2DM have been proposed. Many of them focus on the use of incretin therapies including glucagon like peptide 1 (GLP-1) analogues, GLP-1 receptor agonists and dipeptidyl peptidase IV (DPP-IV) inhibitors. GLP-1 and glucose-dependent insulinotropic polypeptide (GIP) are incretin hormones that stimulate the release of insulin from the pancreas in a glucose-dependent manner ${ }^{(3)}$. Both peptides are natural substrates for the enzyme DPP-IV and are rapidly degraded in vivo resulting in loss of their insulinotropic activity ${ }^{(4)}$. Therefore, DPP-IV inhibitors protect incretins from enzyme cleavage and increase the half-life of the active hormones.

DPP-IV inhibitors (commonly known as gliptins) are an emerging drug class and can be classified, based on their structure, as peptidomimetics or non-peptidomimetic inhibitors ${ }^{(5)}$. Peptidomimetic compounds are designed

Abbreviations: $\alpha$-La, $\alpha$-lactalbumin; $\beta$-Lg, $\beta$-lactoglobulin; CN, caseins; DPP-IV, dipeptidyl peptidase IV; GIP, glucose-dependent insulinotropic polypeptide; GLP-1, glucagon like peptide 1 ; $\mathrm{IC}_{50}$, half-maximal inhibitory concentration; LF, lactoferrin; T2DM, type 2 diabetes mellitus; WP, Whey proteins; ZeinH, zein protein hydrolysate.

*Corresponding author: R. J. FitzGerald, fax 00353-61-331490, email dick.fitzgerald@ul.ie 
to mimic the $\mathrm{N}$-terminal dipeptide that is cleaved by DPP-IV. Vildagliptin (Galvus ${ }^{\circledR}$, Novartis) and Saxagliptin (OnglyzaTM, Bristol Meyers, Squibb) are both peptide-like inhibitors that are approved for use in the European Union and the USA, respectively. Linagliptin (Tradjenta ${ }^{\mathrm{TM}}$, Boehringer Ingelheim) and Sitagliptin (Januvia, Merck) are non-peptidomimetics approved for use in the USA, and Alogliptin (SYR-322, Takeda Pharmaceutical Co.) another nonpeptidomimetic is approved for use in Japan. Most synthetic DPP-IV inhibitors are generally well tolerated; however, some adverse effects of gliptin-based compounds have been reported including headaches, urinary and upper respiratory tract infections ${ }^{(6)}$.

Dietary intervention is accepted as a key component in the prevention and management of T2DM ${ }^{(7)}$. The health enhancing properties of dietary proteins and their constituent peptides are well recognised ${ }^{(8)}$. These bioactive peptides are short peptide sequences, typically less than ten amino acids, encrypted within the structure of a food protein and which can be released by enzyme hydrolysis, microbial fermentation or physical and chemical processing. Once released, the peptides can interact with specific receptors and regulate a variety of physiological functions. In particular, milk proteinderived peptides have beneficial effects on the cardiovascular, gastrointestinal, immune and nervous systems ${ }^{(9)}$. Whey proteins (WP) and caseins $(\mathrm{CN})$ may aid in minimising the physiological effects of T2DM and have been shown to stimulate insulin secretion and regulate blood glucose in T2DM subjects ${ }^{(10,11)}$. Recent research has also shown that peptides derived from milk proteins have DPP-IV inhibitory properties ${ }^{(12,13)}$. The purpose of this review is to consider the role of food protein-derived peptides as potential inhibitors of DPP-IV. While the primary focus is milk protein-derived peptide inhibitors, other food protein-derived peptide inhibitors are also taken into consideration in order to advance our understanding of this topic. The application of milk proteinderived DPP-IV inhibitory peptides will be considered in the context of a nutritional strategy for the management of T2DM.

\section{Incretin hormones}

The incretin effect is the augmentation of insulin secretion elicited by hormones secreted within the gastrointestinal tract in response to nutrient ingestion ${ }^{(3)}$. This phenomenon was demonstrated when oral ingestion of glucose resulted in a greater level of insulin secretion compared with a glucose load delivered through infu$\operatorname{sion}^{(14,15)}$. In healthy subjects, there was a significant augmentation of the insulin response following oral glucose ingestion, approximately threefold higher than the response to glucose infusion. This phenomenon is explained by the existence of gut-derived factors that enhance glucose-stimulated insulin secretion from pancreatic $\beta$-cells. During a meal, incretins, GLP-1 and GIP, are released within the small intestine and act as the primary regulators of glucose homoeostasis ${ }^{(16)}$.
However, in T2DM the incretin response is diminished and equates to approximately $50 \%$ of the response achieved in a healthy adult ${ }^{(17)}$. Post-prandial secretion of GLP-1 is blunted in T2DM, contributing to the reduced insulinotropic response ${ }^{(18)}$. While there is no difference in the secretion level of GIP it has been suggested that the body's response to the insulinotropic actions of this hormone is diminished ${ }^{(19)}$. The reduced response to the insulinotropic actions of GIP may be related to a reduction in receptor expression or reduced $\beta$-cell sensitivity to $\operatorname{GIP}^{(20)}$.

GLP-1 is a pro-glucagon derived peptide produced in the enteroendocrine $(\mathrm{L})$ cells, which are predominantly found in the lower portion of the small intestine. L-cells are nutrient sensitive and GLP-1 is secreted in response to glucose ${ }^{(21)}$, proteins ${ }^{(22,23)}$ peptides $^{(24)}$, amino $\operatorname{acids}^{(25,26)}$ and lipids ${ }^{(27)}$. It has been suggested that the magnitude of the GLP-1 response is related to the extent of exposure of the gut mucosa to the ingested nutrient ${ }^{(28)}$. GLP-1 is released into the circulation in its active form, GLP-1(seven to thirty-six amide) but has a short half-life $(2-4 \mathrm{~min})$. Active GLP-1 is rapidly degraded by DPP-IV, which cleaves the N-terminal dipeptide (His-Ala), producing the inactive GLP-1(nine to thirty-six amide) ${ }^{(29)}$. Approximately $10 \%$ of the active GLP-1 reaches the systemic circulation ${ }^{(30)}$. In addition to its insulin secretion properties, GLP-1 has also been shown to inhibit glucagon secretion ${ }^{(31)}$, both factors contributing to the glucoregulatory properties of the hormone. Other physiological effects of GLP-1 (Fig. 1) include inhibition of gastric acid secretion ${ }^{(32)}$, decreased gastric emptying ${ }^{(33)}$, enhanced satiety and decreased food intake ${ }^{(34)}$.

GIP is a forty-two amino acid peptide which is released from duodenal $\mathrm{K}$ cells in the proximal small intestine. It is secreted in response to nutrient (fat and carbohydrate) ingestion ${ }^{(35)}$ and rises within the first $5-10 \mathrm{~min}$ of the post-prandial period and peaks between 30 and 60 min after nutrient ingestion. Circulating GIP is a combination of the active GIP (one to forty-two) and inactive GIP (three to forty-two) peptide, produced by cleavage of the N-terminal dipeptide (Tyr-Ala) by DPP-IV. In addition to the incretin effect, GIP is also involved in the regulation of fat metabolism (Fig. 1), having a direct effect on adipoyctes to promote TAG storage $^{(36)}$. Post-prandial plasma concentrations of GIP are approximately tenfold higher than GLP-1 ${ }^{(30)}$. Some infusion studies have suggested that GLP-1 has greater insulinotropic potency than $\operatorname{GIP}^{(19,31)}$. However, the differences in concentration and potency seem to have a compensatory effect as it has been demonstrated that both hormones act cooperatively with respect to their incretin effect ${ }^{(19,37)}$.

Incretin hormone action is regulated through specific receptors (GLP-1R and GIP-R). Both G-protein coupled receptors are expressed in a variety of tissues. GLP-1 receptors are expressed on pancreatic $\beta$ - and $\alpha$-cells whereas GIP receptors are found only on $\beta$-cells ${ }^{(3)}$. In addition, GIP receptors are expressed on adipose tissue and GLP receptors in the heart, lung, brain, gastrointestinal tract, peripheral and central nervous system. 


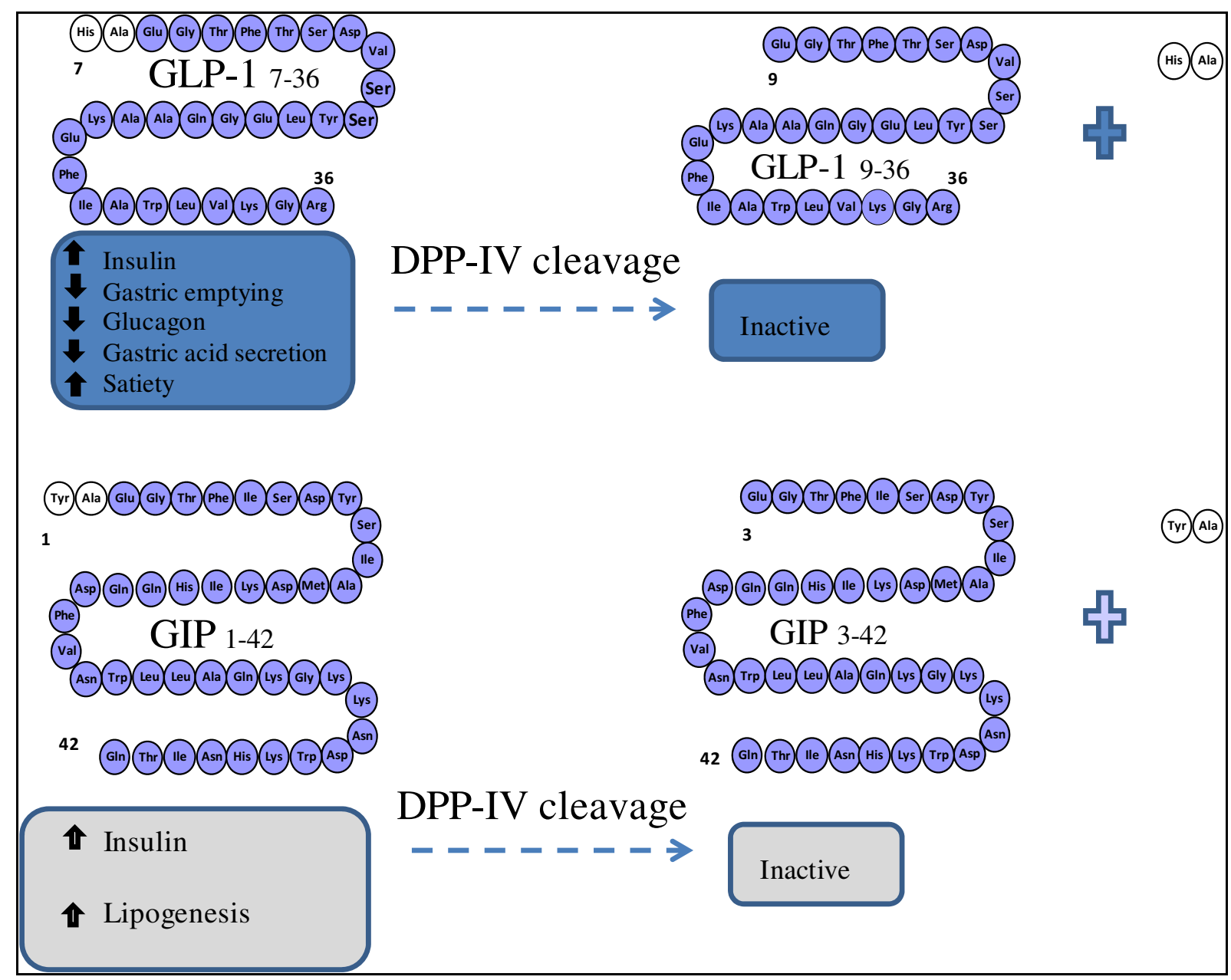

Fig. 1. (Colour online) Physiological functions of the active incretin hormones, glucagon like peptide 1 (GLP-1) and glucose-dependent insulinotropic polypeptide (GIP) and the relationship between incretin hormones and dipeptidyl peptidase IV (DPP-IV) activity.

Binding of GLP-1 or GIP to their receptor activates intracellular signalling mechanisms, which causes an elevation of cAMP and an increase in protein kinase A. GIP and GLP-1 can act synergistically with glucose to close ATP-sensitive $\mathrm{K}^{+}$channels. This facilitates membrane depolarisation leading to an increase in intracellular calcium and ultimately insulin release via exocytosis of insulin containing granules ${ }^{(38)}$.

Mice lacking DPP-IV had improved blood glucose regulation and lower degradation of GIP and GLP-1 ${ }^{(39)}$. DPP-IV deficient rats had better glucose tolerance, increased insulin and higher concentrations of active GLP-1 ${ }^{(40)}$. Furthermore, DPP-IV knockout mice did not develop glucose intolerance or diabetes even after 20 weeks on a high-fat diet ${ }^{(41)}$. In human subjects, chemical inhibitors of DPP-IV have been used to prevent the degradation of intact incretins in both healthy ${ }^{(42)}$ and T2DM subjects ${ }^{(43)}$. In healthy adults, treatment with Vildaglitin increased active GLP-1 concentration twoto threefold relative to the placebo and inhibited DPP-IV activity for up to $95 \%$ for $4 \mathrm{~h}$. In the T2DM patients, 4 weeks treatment with the DPP-IV inhibitor (LAF237) significantly increased basal and post-prandial active GLP- 1 concentration by approximately $50 \%$ relative to the placebo. Meanwhile, plasma DPP-IV activity was significantly inhibited approximately $99 \%$ at $4 \mathrm{~h}$ and was inhibited by $60 \%$ after $24 \mathrm{~h}$. Post-prandial glucose concentrations were significantly lower which correlated with the reduction in plasma glucagon; however, there was no effect on plasma insulin. Therefore, DPP-IV plays an important role in the regulation of incretin hormone metabolism and glucose homoeostasis. The application of natural compounds that inhibit the activity of this enzyme could represent a useful strategy to increase the half-life of active incretin hormones.

\section{Structure and function of dipeptidyl peptidase IV}

DPP-IV, also known as adenosine deaminase binding protein or CD26 (EC 3.4.14.5), is a ubiquitous aminodipeptidase. It is expressed on the surface of several cell types including lymphocytes, monocytes and in tissues from the pancreas, kidney, liver and gastrointestinal tract. Soluble DPP-IV is found in plasma and cerebrospinal fluid. The widespread expression of DPP-IV 


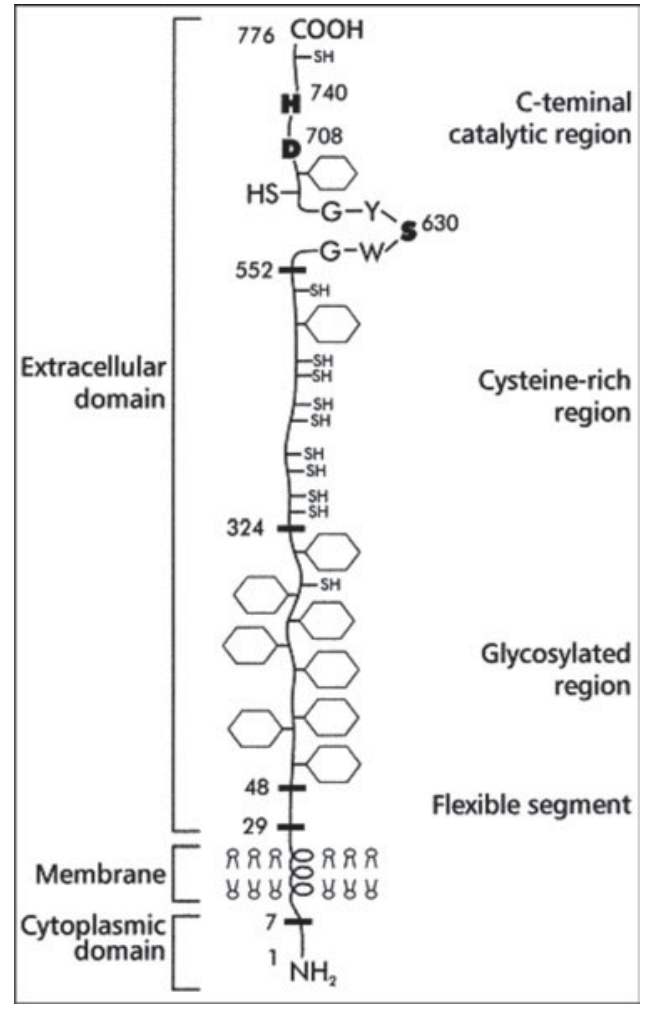

Fig. 2. Main structural features of human dipeptidyl peptidase $\mathrm{IV}^{(45)}$. Reproduced with permission from Elsevier.

suggests that it is associated with a variety of physiological functions including immunoregulation ${ }^{(44)}$, endocrine activity and the degradation of peptide hormones ${ }^{(45)}$. The immunological activities of DPP-IV such as T-cell stimulation, which rely on protein binding, are mediated by the external surface of the enzyme ${ }^{(46)}$. The enzymatic incretin degradation and immunological functions of DPP-IV are located at different sites within the enzyme $^{(44)}$ which suggests that these functions may be independent of one another.

DPP-IV is a dimeric, transmembrane, glycoprotein $(220 \mathrm{kDa}-2 \times 110 \mathrm{kDa}$ subunits). Each subunit is anchored in the plasma membrane by a hydrophobic helix consisting of seven N-terminal amino acids. The large globular extracellular domain contains a flexible segment linked to a glycosylated region, followed by a cysteine-rich region, linked to $\mathrm{C}$-terminal catalytic region which contains a catalytic triad consisting of Ser-AspHis residues (Fig. 2).

The C-terminal catalytic region contains the active site sequence, Gly-Trp-Ser-Tyr-Gly, which has serine exopeptidase activity. The three-dimensional structure of DPP-IV determines substrate specificity for proteolytic cleavage $^{(6)}$. The enzyme active site forms a hydrophobic pocket within the interior of the folded structure; therefore, only elongated peptides or unfolded proteins can access this region. The active site is accessible in two ways, via an opening in the $\beta$-propeller domain or via a large side opening formed at the interface of the $\beta$-propeller and $\alpha / \beta$ hydrolase domain ${ }^{(47)}$. The structural

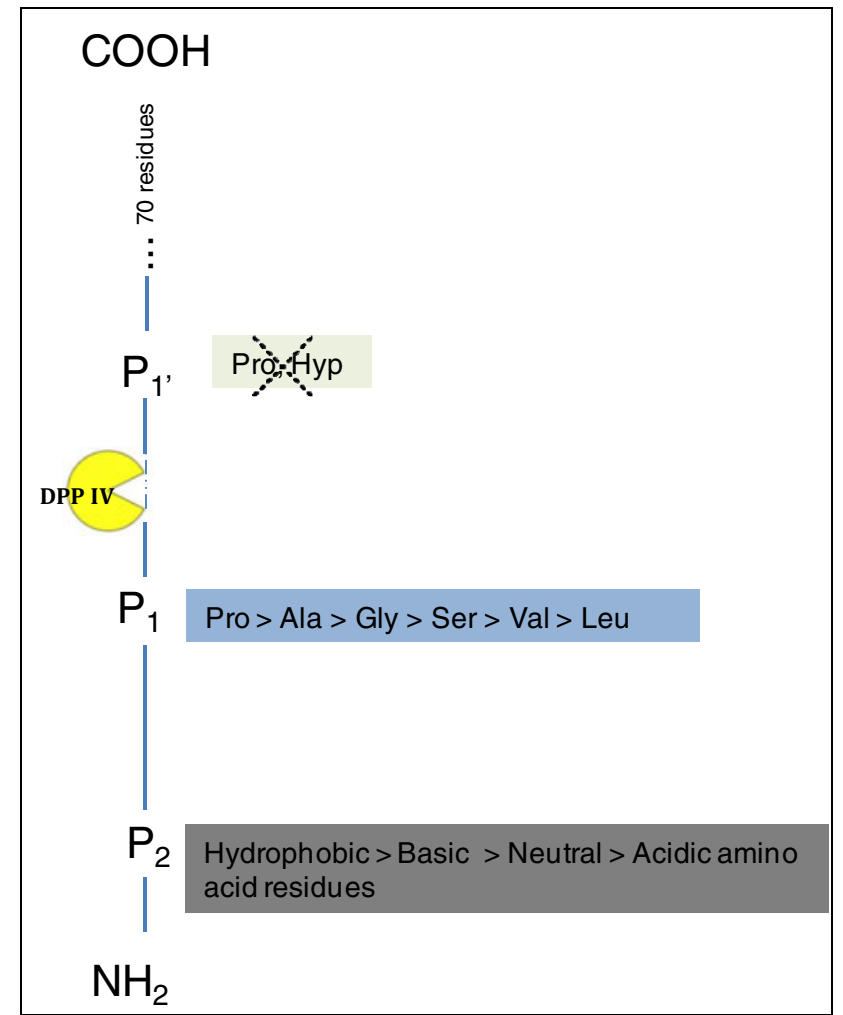

Fig. 3. (Colour online) Specificity of substrate cleavage by dipeptidyl peptidase IV.

features of DPP-IV suggest that the most likely entrance to the active site is via the large side opening ${ }^{(48)}$. This is the shortest and most directly accessible route to the active site. The negative charge of this domain attracts peptides with a positively charged N-terminus. In addition, if the peptide enters via the large side opening it will be correctly orientated for cleavage. It has also been proposed that a secondary binding site exists within the structure of DPP-IV. These binding sites can influence catalytic activity of DPP-IV in particular the selectivity of the enzyme towards the substrate ${ }^{(49)}$. The specificity for the amino acid located at position $\mathrm{P}_{1}$ decreases with increasing substrate length. Peptide binding to the secondary binding site is influenced by the amino acid sequence at the N-terminal region of the peptide in particular at positions $\mathrm{P}_{4}-\mathrm{P}_{8}$.

The widespread expression of DPP-IV means that it can easily access and inactivate a wide variety of biological regulatory peptides, including GIP, GLP-1, growth hormone, peptide YY and neuropeptide $\mathrm{Y}^{(45)}$. DPP-IV has a relatively strict substrate specificity and principally cleaves proline (Xaa-Pro; where Xaa is any amino acid) or alanine (Xaa-Ala) containing dipeptides from the N-terminal of a polypeptide (Fig. 3). While Pro or Ala are preferred at position $\mathrm{P}_{1}$ lower cleavage rates exist for peptides containing Ser, Gly, Val and Leu in this position ${ }^{(29,50)}$. Hydrophobic and basic residues at position $\mathrm{P}_{2}$ increase the susceptibility for cleavage compared with acidic residues. Peptides containing Pro or hydroxylproline at position $\mathrm{P}_{1^{\prime}}$ are not cleaved. Kinetic studies 


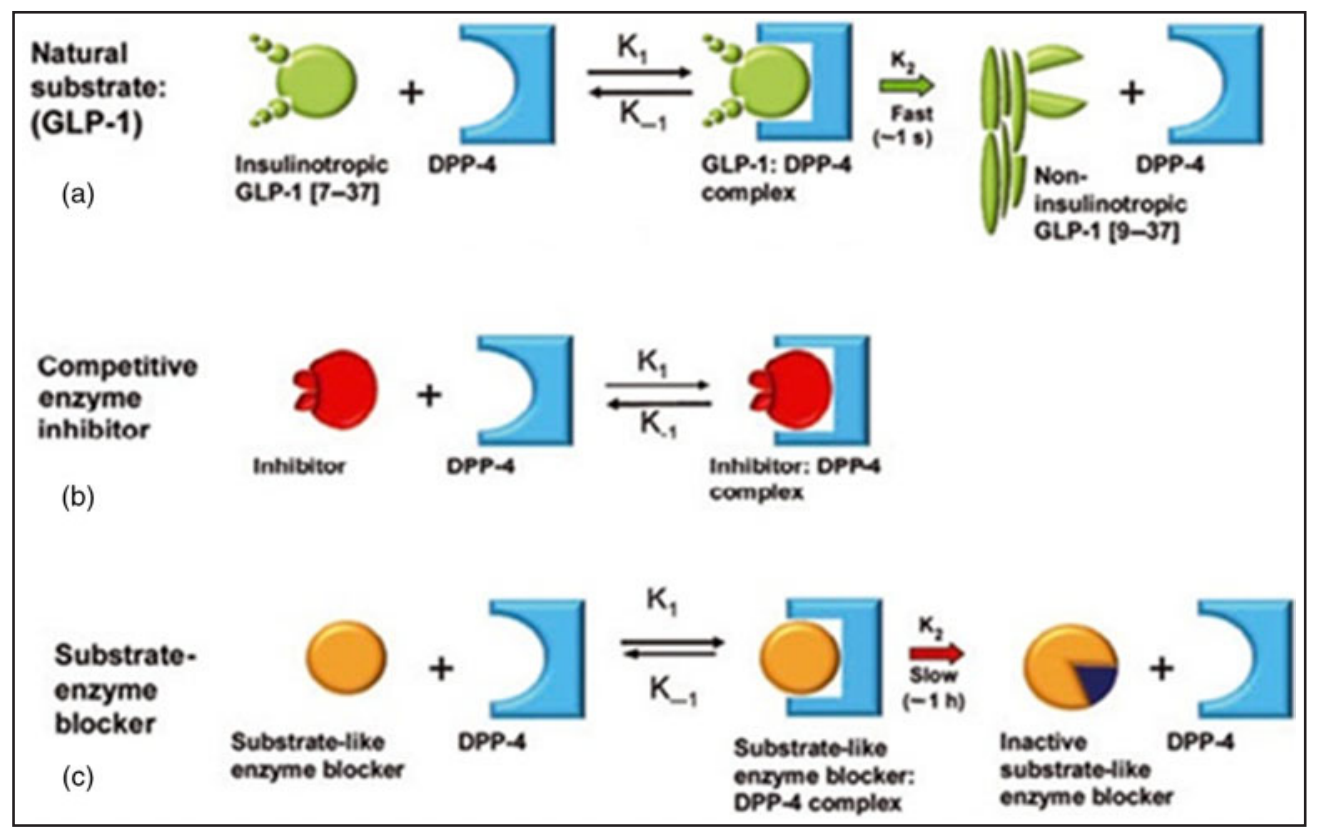

Fig. 4. (Colour online) Binding kinetics for (a) natural substrates of dipeptidyl peptidase IV (DPP-4) and $(b, c)$ potential mechanisms of DPP-IV inhibition ${ }^{(51)}$. GLP-1, glucagon like peptide 1. Reproduced with permission from John Wiley \& Sons.

have shown that optimal cleavage rates occur between pH 7.5 and 8.5 and at $37^{\circ} \mathrm{C}^{(45)}$.

\section{Mode of action of dipeptidyl peptidase IV inhibitors}

The mode of action of DPP-IV inhibitors is schematically illustrated in Fig. 4. Natural substrates of DPP-IV, including GLP-1, associate with the active site (Fig. 4a). If GLP-1 is in the correct configuration state it will be locked into the active site forming a GLP-1: DPP-IV complex. The peptide bond between amino acids at positions $\mathrm{P}_{1}$ and $\mathrm{P}_{1^{\prime}}$ will be weakened ${ }^{(51)}$. The bond is rapidly degraded and the inactive GLP-1 dissociates from the active site. The overall kinetics of this process are determined by the rate limiting step, which is dissociation from the active site. Diprotin A (IlePro-Ile) and B (Val-Pro-Ile), originally isolated from the culture filtrates of Bacillus cereus BMF673-RF1, are two examples of substrate type inhibitors of DPP-IV with half-maximal inhibitory concentration $\left(\mathrm{IC}_{50}\right)$ values in the micromolar range ${ }^{(52)}$.

A typical competitive enzyme inhibitor will compete with a natural substrate for binding to the active site. Competitive enzyme inhibitors (Fig. 4b) generally follow Michaelis-Menten kinetics with dose-dependent activity and $\mathrm{IC}_{50}$ values in the micro to pico molar range ${ }^{(45)}$. A number of peptides have been shown to act as competitive inhibitors of DPP-IV. In particular, Procontaining peptides (e.g. Ile-Pro) have been shown to have $\mathrm{IC}_{50}$ values in the low micromolar range ${ }^{(53)}$. A second mechanism of competitive inhibition has been proposed $^{(51)}$. This involves formation of an enzymeinhibitor complex (Fig. 4c). This substrate enzyme complex binds the active site of DPP-IV. The association causes the compound to be locked into the active site. The rate of dissociation from the active site occurs at a slower rate than for the standard competitive inhibitor, resulting in a more prolonged DPP-IV inhibition. This type of substrate-like enzyme blocker inhibition has been proposed as a mechanism of action for the synthetic inhibitor Vildagliptin ${ }^{(51,54)}$.

Non-competitive inhibitors can interact with secondary binding sites (e.g. receptor sites and substrate recognition site) in the native structure of the DPP-IV molecule ${ }^{(55)}$. This binding modifies the substrate specificity and catalytic activity of DPP-IV. Longer peptides (thirty to fifty amino acids) have been shown to act as non-competitive inhibitors by forming interactions at the dimerisation interface and blocking the formation of the DPP-IV active $\operatorname{dimer}^{(56)}$. Amino acid substitutions at specific locations within the peptide can alter the mode of inhibition and potency of inhibition ${ }^{(13,57)}$. In addition, there is some evidence that the peptides can function by mixed modes of inhibition $^{(57)}$. This may involve the binding of two inhibitor compounds at two different sites on the enzyme.

\section{Food protein-derived dipeptidyl peptidase IV peptide inhibitors}

Proteins and peptides have a wide variety of biological activities that may benefit human health. In particular, bioactive peptide with beneficial effects on the cardiovascular, gastrointestinal, immune and nervous systems have been identified ${ }^{(58)}$. The bioactivity of these peptides is typically related to their amino acid sequence and size ${ }^{(59)}$. As already mentioned, recent research has identified food protein-derived peptides with DPP-IV inhibitory activity ${ }^{(60)}$. 
Table 1. Food protein hydrolysate derived peptides with dipeptidyl peptidase IV inhibitory activity

\begin{tabular}{|c|c|c|c|}
\hline Substrate & Sequence & $\mathrm{IC}_{50}(\mu \mathrm{M})$ & Reference \\
\hline Atlantic salmon skin & $\begin{array}{l}\text { Gly-Pro-Gly-Ala } \\
\text { Gly-Pro-Ala-Glu }\end{array}$ & $\begin{array}{l}49.6 \\
41.9\end{array}$ & (61) \\
\hline Tuna cooking juice & $\begin{array}{l}\text { Pro-Gly-Val-Gly-Gly-Pro-Leu-Gly-Pro-Ile-Gly-Pro-Cys-Tyr-Glu } \\
\text { Cys-Ala-Tyr-Gln-Trp-Gln-Arg-Pro-Val-Asp-Arg-Ile-Arg } \\
\text { Pro-Ala-Cys-Gly-Gly-Phe-Tyr-Ile-Ser-Gly-Arg-Pro-Gly }\end{array}$ & $\begin{array}{l}116 \\
78 \\
96.4\end{array}$ & (62) \\
\hline Japanese rice bran & $\begin{array}{l}\text { Leu-Pro } \\
\text { lle-Pro } \\
\text { Met-Pro } \\
\text { Val-Pro } \\
\text { Arg-Pro } \\
\text { Thr-Pro } \\
\text { Leu-Pro } \\
\text { Lys-Pro } \\
\text { His-Pro } \\
\text { Tyr-Pro } \\
\text { Phe-Pro } \\
\text { Trp-Pro } \\
\text { Pro-Pro } \\
\text { Ser-Pro } \\
\text { Ala-Pro } \\
\text { Gly-Pro } \\
\text { Pro-Ile }\end{array}$ & $\begin{array}{l}2400 \\
410 \\
870 \\
880 \\
2240 \\
2370 \\
2370 \\
2540 \\
2820 \\
3170 \\
3630 \\
4530 \\
5860 \\
5980 \\
7950 \\
\text { NA } \\
\text { NA }\end{array}$ & (53) \\
\hline 更 & $\begin{array}{l}\text { Leu-Pro-GIn-Asn-Ile-Pro-Pro-Leu } \\
\text { Leu-Pro-Gln-Asn-Ile-Pro-Pro } \\
\text { Pro-Gln-Asn-Ile-Pro-Pro-Leu } \\
\text { Leu-Pro-GIn } \\
\text { Val-Pro-Ile-Thr-Pro-Thr } \\
\text { Val-Pro-Ile-Thr-Pro-Thr-Leu } \\
\text { Phe-Pro-Gly-Pro-Ile-Pro-Asp } \\
\text { Pro-Gly-Pro-Ile-His-Asp-Ser } \\
\text { Ile-Pro-Pro-Leu-The-Gln-Thr-Pro-Val } \\
\text { Val-Pro-Pro-Phe-Ile-Gln-Pro-Glu } \\
\text { Tyr-Pro-Phe-Pro-Gly-Pro-Ile-Pro-Asp }\end{array}$ & $\begin{array}{l}46 \\
160 \\
1500 \\
82 \\
130 \\
110 \\
260 \\
1000 \\
1300 \\
2500 \\
670\end{array}$ & (63) \\
\hline $\begin{array}{l}\beta \text {-lactoglobulin } \\
\beta \text {-lactoglobulin }\end{array}$ & $\begin{array}{l}\text { Val-Ala-Gly-Thr-Trp-Tyr } \\
\text { Ile-Pro-Ala }\end{array}$ & $\begin{array}{l}174 \\
49\end{array}$ & $\begin{array}{l}(64) \\
(65)\end{array}$ \\
\hline$\beta$-lactoglobulin & $\begin{array}{l}\text { Ile-Pro-Ala-Val-Phe } \\
\text { Ile-Pro-Ala-Val-Phe-Lys } \\
\text { Val-Leu-Val-Leu-Asp-Thr-Asp-Tyr-Lys } \\
\text { Thr-Pro-Glu-Val-Asp-Asp-Glu-Ala-Leu-Glu-Lys }\end{array}$ & $\begin{array}{l}45 \\
143 \\
424 \\
320\end{array}$ & (66) \\
\hline Milk protein & $\begin{array}{l}\text { Glu-Lys } \\
\text { Gly-Leu } \\
\text { Ala-Leu } \\
\text { Val-Ala } \\
\text { Trp-Val } \\
\text { Phe-Leu } \\
\text { His-Leu } \\
\text { Ser-Leu }\end{array}$ & $\begin{array}{l}3216 \\
2615 \\
882 \\
168 \\
65 \\
399 \\
143 \\
2517\end{array}$ & (13) \\
\hline
\end{tabular}

$\mathrm{IC}_{50}$, half-maximal inhibitory concentration; NA, no inhibitory activity.

Enzyme hydrolysates of Atlantic salmon skin gelatin have been shown to possess DPP-IV inhibitory activity and this activity was dependent on the specificity of the enzyme used to generate the hydrolysate ${ }^{(61)}$. The most potent hydrolysate was generated using Flavorzyme ${ }^{\circledR}$ and the resulting hydrolysate had $45 \%$ DPP-IV inhibition at $5.0 \mathrm{mg} / \mathrm{ml}$. Further molecular mass fractionation, yielded a $<1 \mathrm{kDa}$ fraction, which had $61 \%$ DPP-IV inhibition at $2.0 \mathrm{mg} / \mathrm{ml}$ and an $\mathrm{IC}_{50}$ value of
$1.35 \mathrm{mg} / \mathrm{ml}$. This low-molecular-weight fraction was further purified by reversed-phase high-performance liquid chromatography and the most potent fraction had an $\mathrm{IC}_{50}$ value of $0.57 \mathrm{mg} / \mathrm{ml}$. Within this fraction, two DPP-IV inhibitory peptides were identified (GlyPro-Gly-Ala and Gly-Pro-Ala-Glu; Table 1) which had $\mathrm{IC}_{50}$ values of 49.6 and $41.9 \mu \mathrm{M}$, respectively.

Hydrolysis of the East Asian azuki bean with proteolytic or microbial enzymes produced hydrolysates with 
DPP-IV inhibitory properties ${ }^{(67)}$. The most potent hydrolysate of azuki bean was generated using Umanizyme $G^{\circledR}$ and was further fractionated through a $10 \mathrm{kDa}$ membrane. The resulting permeate had $52 \%$ DPP-IV inhibition at $1.0 \mathrm{mg} / \mathrm{ml}$. Bioinformatic analysis predicted that the Native American amaranth protein contains peptides that have DPP-IV inhibitory activity ${ }^{(68)}$. Tryptic digests of amaranth produced hydrolysates with dose-dependent increase in inhibitory activity and which had $\mathrm{IC}_{50}$ values between 1.2 and $2.0 \mathrm{mg} / \mathrm{ml}^{(56)}$. Removal of the larger protein/peptide material by ultrafiltration $(10 \mathrm{kDa})$ increased the DPP-IV inhibitory activity by $50-100 \%$ and the $10 \mathrm{kDa}$ ultrafiltration permeates had $\mathrm{IC}_{50}$ values between 1.0 and $1.6 \mathrm{mg} / \mathrm{ml}$. In silico analysis of the amaranth globulins with tryspin identified four peptides, which contained thirteen to fifty amino acid residues (11S amaranth globulin $\mathrm{f}$ (1-13), f(18-39), f(69-81), f(92-143)) and which may be responsible for the inhibitory activity. Hydrolysates derived from hen's egg displayed DPP-IV inhibitory activity $^{(69)}$. The inhibitory activity varied depending on the specificity of the enzyme used, with up to fourfold differences in the $\mathrm{IC}_{50}$ values (e.g. 1.5 v. $0.4 \mathrm{mg} / \mathrm{ml}$ ) for lysozyme hydrolysates.

Japanese rice bran has also been used to generate peptides with DPP-IV inhibitory properties ${ }^{(53)}$. Two hydrolysates were prepared using fungal and bacterial enzyme preparations (Umanizyme $G^{\circledR}$ and Bioprase SP) and had $\mathrm{IC}_{50}$ values of 2.3 and $26.4 \mathrm{mg} / \mathrm{ml}$, respectively. The tenfold difference in the inhibitory activity further highlights the importance of the enzyme specificity used to release DPP-IV inhibitory peptides. The Umanizyme $G^{\circledR}$ hydrolysate was further purified by gel filtration chromatography followed by reversed-phase HPLC and two DPP-IV inhibitory dipeptides (Leu-Pro and Ile-Pro) were identified (Table 1). Tuna cooking juice has been used to generate peptides with DPP-IV inhibitory activity. Hydrolysates were generated using two fungal endoproteinases in order to establish the optimal conditions to generate DPP-IV inhibitory peptides $^{(62)}$. Maximum cleavage of peptides occurred after $1-2 \mathrm{~h}$ of hydrolysis and DPP-IV inhibition was $40-45 \%$ at $10.0 \mathrm{mg} / \mathrm{ml}$. Hydrolysates were further purified by gel filtration chromatography $(40 \%$ inhibition at $5.0 \mathrm{mg} / \mathrm{ml})$ and reversed-phase HPLC ( $\sim 60 \%$ inhibition at $5.0 \mathrm{mg} / \mathrm{ml}$ ) in order to enrich for peptides with DPP-IV inhibitory activity. Three peptides (Pro-GlyVal-Gly-Gly-Pro-Leu-Gly-Pro-Ile-Gly-Pro-Cys-TyrGlu, Cys-Ala-Tyr-Gln-Trp-Gln-Arg-Pro-Val-AspArg-Ile-Arg and Pro-Ala-Cys-Gly-Gly-Phe-Tyr-IleSer-Gly-Arg-Pro-Gly) with molecular mass between 1304 and $1690 \mathrm{Da}$, isolated from a tuna cooking juice hydrolysate, were determined to be responsible for the DPP-IV inhibitory activity (Table 1). Synthetic peptides matching these sequences displayed a dose-dependent increase in DPP-IV inhibition with $\mathrm{IC}_{50}$ values between 78 and $116 \mu \mathrm{M}$. These peptide sequences contained thirteen to fifteen amino acid residues, making them longer than typical DPP-IV inhibitory peptides. There were some structural similarities between the three peptides, each peptide contained at least one Pro residue and all the peptides had a high proportion of hydrophobic amino acid residues.

Simulated gastrointestinal digestion of the three tuna cooking juice-derived peptides had up to $22 \%$ higher DPP-IV inhibitory activity following simulated gastrointestinal digestion $^{(62)}$. This suggests that the longer peptides were degraded to smaller fragments producing a greater number of peptides with inhibitory activity and/ or more potent peptides. The intestinal stability of the DPP-IV inhibitory peptides can be assessed using amino acid clustering models ${ }^{(70)}$. This predicts stability of a peptide under simulated intestinal digestion and was recently used to evaluate the stability of a potent DPP-IV inhibitory peptide, Trp-Val. This peptide was classified as neutral, that is, between 25 and $75 \%$ of the peptide was predicted to remain intact after $60 \mathrm{~min}$ of simulated intestinal digestion. Free amino acids, with the exception of Leu, Met and Trp, did not inhibit DPP-IV. Some dipeptides containing these amino acids were shown to be inactive (e.g. Arg-Trp, Val-Trp and Ile-Trp), whereas other peptides (e.g. Trp-Val, PheLeu and His-Leu) were more potent DPP-IV inhibitors than the constituent amino acids. It was therefore suggested that depending on their intestinal stability the DPP-IV inhibitory properties of dipeptide inhibitors may be increased or decreased in vivo ${ }^{(71)}$.

\section{Milk protein-derived peptide inhibitors}

Milk is a good source of nitrogen and essential amino acids. The major protein components of milk, CN $(80 \%)$ and WP $(20 \%)$, are suitable precursors to generate DPP-IV inhibitory peptides ${ }^{(60)}$. CN is the predominant protein in milk and is composed of $\alpha_{\mathrm{S}^{-}}, \alpha_{\mathrm{S}^{-}}, \beta-$ and $\kappa-\mathrm{CN}^{(72)}$. $\mathrm{CN}$ have a relatively open and disordered structure which makes them highly susceptible to proteolysis. In addition, $\mathrm{CN}$ contain a large amount of Pro residues with abundances of $16.7,11.8,8.5$ and $4.8 \%$ for $\beta-, \kappa-, \alpha_{\mathrm{S}^{-}}$and $\alpha_{\mathrm{S} 2}-\mathrm{CN}$, respectively ${ }^{(8)}$. Therefore, $\mathrm{CN}$-derived peptides are likely to contain the Xaa-Pro motif within their sequences. This increases the susceptibility to cleavage by DPP-IV or other post Pro cleaving enzymes and the potential for the release of peptides with DPP-IV inhibitory activity. CN protein hydrolysates enriched in short peptides have been shown to inhibit DPP-IV activity ${ }^{(73)}$. Candidate inhibitory peptides were identified within the hydrolysates and these peptides had $\mathrm{IC}_{50}$ values between 5 and $121 \mu \mathrm{M}$. The most potent sequence was Leu-Pro-Leu which had an $\mathrm{IC}_{50}$ value of $5 \mu \mathrm{M}$. There were some structural similarities between the potent CN-derived DPP-IV inhibitory peptides as they generally contained a Pro residue located in the $\mathrm{P}_{1-4} \mathrm{~N}$-terminal region and predominantly as the penultimate residue. In addition, hydrophobic amino acid residues Leu, Val and Phe were typically located close to the Pro residue. DPP-IV inhibitory peptides have been isolated from a water-soluble extract of a Gouda-type cheese ${ }^{(63)}$. The most potent peptide was an octapeptide ( $\beta-\mathrm{CN}$ f $70-77$, Table 1) which had an $\mathrm{IC}_{50}$ value of $46 \mu \mathrm{M}$. Peptide derivatives: 
Leu-Pro-Gln-Asn-Ile-Pro-Pro, Pro-Gln-Asn-Ile-ProPro-Leu and Leu-Pro-Gln had lower inhibitory activity (Table 1) suggesting that the amino acid sequence is an important determinant of activity.

WP have a globular structure and are composed of five major proteins: $\beta$-lactoglobulin $(\beta-\mathrm{Lg}), \alpha$-lactalbumin $(\alpha$-La), bovine serum albumin, immunoglobulins and a number of minor proteins such as lactoferrin (LF) and lactoperoxidase. Each individual WP has different physicochemical properties, which can be modified by enzymatic hydrolysis and hydrolysis of WP has been shown to release DPP-IV inhibitory peptides ${ }^{(13,64-66)}$. Digestion of WP with pepsin and pancreatin generated peptides with DPP-IV inhibitory activity and peptic digestion produced the most potent hydrolysate with an $\mathrm{IC}_{50}$ value of $0.075 \mathrm{mg} / \mathrm{ml}$. However, the peptides responsible for the activity have not been identified ${ }^{(12)}$. In silico prediction suggests that $\beta-\mathrm{Lg}$ contains approximately three times more peptide sequences with potential DPP-IV inhibitory activity than $\alpha-\mathrm{La}^{(60)}$. This was demonstrated by tryptic digestion of the two major WP where the $\beta$-Lg hydrolysate displayed dose-dependent DPP-IV inhibition while the $\alpha$-La hydrolysate had no inhibitory activity ${ }^{(64)}$. Chromatographic isolation and purification of the $\beta-\mathrm{Lg}$ hydrolysate enabled identification of the active peptide, $\beta-\mathrm{Lg}$ f15-20 (Table 1). The activity was confirmed using the synthetic peptide sequence, which also displayed a concentrationdependent inhibitory effect and had an $\mathrm{IC}_{50}$ value of $174 \mu \mathrm{M}$.

An LF hydrolysate with DPP-IV inhibitory activity has been recently identified and this hydrolysate had an $\mathrm{IC}_{50}$ value of $1.088 \mathrm{mg} / \mathrm{ml}^{(13)}$. While the $\mathrm{IC}_{50}$ value was not significantly different from other WP hydrolysates this was the first report of an LF hydrolysate with DPP-IV inhibitory activity. In addition to the DPP-IV inhibitory activity the LF hydrolysate was also found to have antioxidant activity. Diabetes is associated with an increase in oxidative stress ${ }^{(74)}$. Therefore, the LF hydrolysate may have potential in the management of T2DM through the multifunctional properties of DPP-IV inhibition and antioxidant activity.

The DPP-IV inhibitory activity of WP and CN has been compared ${ }^{(12)}$. In general, CN-derived hydrolysates had significantly higher DPP-IV inhibitory activity than WP hydrolysates. In some instances, $\mathrm{CN}$ hydrolysates had twofold higher inhibitory activity than the equivalent WP hydrolysate produced with the same enzyme. For all WP and CN hydrolysates, DPP-IV inhibitory activity ranged from 15 to $51 \%$ (at $0.487 \mathrm{mg} / \mathrm{ml}$ ) and was dependent on the specificity of the proteolytic enzyme. The greater level of inhibitory activity in the $\mathrm{CN}$-derived hydrolysates is in agreement with the fact that the $\mathrm{CN}$ proteins contain a greater proportion of inhibitory peptide motifs within their primary sequence. In another study, $\mathrm{CN}$ and WP hydrolysates were reported to have similar DPP-IV inhibitory activity ${ }^{(13)}$. The higher than expected $\mathrm{IC}_{50}$ values for the $\mathrm{CN}$ hydrolysates may be due to the fact that not all possible DPP-IV inhibitory peptides were released during hydrolysis. Lineweaver and Burk analysis revealed that all the DPP-IV inhibitory hydrolysates tested were competitive inhibitors of DPP-IV, indicating direct interaction of the milk-derived peptides with the active site of DPP-IV ${ }^{(13)}$.

Milk protein-derived peptides have been shown to possess DPP-IV inhibitory properties (Table 1). A $\beta$ - $\mathrm{Lg}$ derived tri-peptide (Ile-Pro-Ala) can be released from $\beta$-Lg by digestion with proteinase $\mathrm{K}^{(75)}$ and when evaluated in vitro it was found to have an $\mathrm{IC}_{50}$ value of $49 \mu \mathrm{M}^{(65)}$. This peptide shares some structural similarities with the reference inhibitor Ile-Pro-Ile although the $\mathrm{IC}_{50}$ value was approximately fourteenfold higher $(3.5 v$. $49 \mu \mathrm{M}$ for Ile-Pro-Ile and Ile-Pro-Ala, respectively). Related peptide sequences, Ile-Pro-Ala-Val-Phe and Ile-Pro-Ala-Val-Phe-Lys had $\mathrm{IC}_{50}$ values of 45 and $143 \mu \mathrm{M}$, respectively ${ }^{(66)}$. The addition of Val and Phe residues led to a small reduction of the DPP-IV $\mathrm{IC}_{50}$ value compared with the truncated peptide Ile-Pro-Ala (Table 1). However, further addition of a Lys residue resulted in a threefold increase in the $\mathrm{IC}_{50}$ value (Table 1) which was attributed to a decrease in peptide hydrophobicity. This highlights the importance of the amino acid sequence to the potency of DPP-IV inhibition. Milk protein-derived dipeptides have been studied for their DPP-IV inhibitory activity ${ }^{(13)}$ and from the twelve dipeptides studied eight were DPP-IV inhibitors (Table 1). The most potent peptide identified was TrpVal, a non-competitive DPP-IV inhibitor, which had an $\mathrm{IC}_{50}$ value of $65 \mu \mathrm{M}$. In addition, Trp-Val had antioxidant properties, which highlight the dual functionality of some milk-derived peptides.

\section{Structure-activity relationship of peptide inhibitors}

The structure-function relationship and the mechanisms of peptide induced DPP-IV inhibition have not been fully elucidated. As outlined earlier, the majority of research conducted to date has focused on the production and identification of DPP-IV inhibitory peptides from food protein hydrolysates. However, some structural characteristics of DPP-IV inhibitory peptides have been identified. Potent DPP-IV inhibitory peptides typically contain two to seven amino acid residues with Pro or Ala as the penultimate amino acid at the N-terminus ${ }^{(73)}$. It has been shown that the sequence of the peptide rather than its amino acid composition influences DPP-IV inhibitory activity. For example, the dipeptides Ile-Pro and Trp-Val had DPP-IV inhibitory activity (Table 1) whereas the reverse peptides Pro-Ile and Val-Trp, respectively had no inhibitory activity ${ }^{(13,53)}$. In addition, the N-terminal residue of Pro containing dipeptides (Xaa-Pro) was shown to influence the DPP-IV inhibitory activity $^{(53)}$. The dipeptide Leu-Pro had a fivefold higher $\mathrm{IC}_{50}$ value than Ile-Pro $(2.37$ v. $0.41 \mathrm{~mm})$. The dipeptides Leu-Leu and Val-Val both show DPP-IV inhibitory activity, however, Leu-Leu-Phe and Leu-Val, did not have any DPP-IV inhibitory activity ${ }^{(65)}$. This indicates that the residue present at the $\mathrm{N}$-terminal also influences inhibitory activity. 
The structural characteristics outlined earlier have been identified by the analysis of protein hydrolysates and synthetic peptides. Other methods such as in silico analysis and molecular docking are complimentary techniques that can also be used to identify potential inhibitory peptides and predict their mechanism of action. An in silico evaluation of six milk proteins $\left(\alpha_{\mathrm{S1}^{-}}, \beta-, \kappa-\mathrm{CN}\right.$, $\beta$ - $\mathrm{Lg}, \alpha-\mathrm{La}$ and $\mathrm{LF}$ ) found that all proteins contained DPP-IV inhibitory peptides within their primary sequence $^{(60)}$. In total, 211 peptide fragments predicted to have DPP-IV inhibitory activity were found in the primary sequence of the six milk proteins, Leu-Leu and Leu-Val occurred most frequently. $\beta-\mathrm{CN}$ had the greatest proportion $(0.249$; number of peptides with activity/number of amino acids residues in the protein) of peptide sequences with DPP-IV inhibitory activity while $\alpha$-La had the lowest (0.041). Such in silico evaluations give an indication of the potential occurrence of DPP-IV inhibitory peptides within the milk proteins. However, if enzyme hydrolysis is to be used as an effective strategy to release DPP-IV inhibitory peptides then identification of enzymes with appropriate specificity and selectivity to release the peptides or peptide precursors is essential. In addition, there may be other inhibitory peptide sequences within the milk proteins which have not yet been identified.

Molecular docking approaches are typically used in drug discovery ${ }^{(76)}$. More recently, docking strategies have been used as virtual screening tools to study peptide-enzyme interactions and to predict inhibitory activity $^{(77)}$. This technique was used to screen dipeptides for their angiotensin-converting enzyme inhibitory activity. This has led to the identification of new, potent angiotensin-converting enzyme-inhibitory dipeptides (Asp-Trp, Trp-Pro ${ }^{(78)}$ ). Molecular docking, with Autodock Vina, has been utilised to study the interaction of amino acids and dipeptides with xanthine oxidase and DPP-IV $^{(71)}$. Docking of competitive, DPP-IV peptide inhibitors to its active site revealed that interactions occurred through hydrogen bonds and hydrophobic interactions. In theory, a low Vina score indicates a higher binding affinity and would predict a low $\mathrm{IC}_{50}$ value. However, the DPP-IV $\mathrm{IC}_{50}$ values obtained for the milk-derived dipeptides did not correlate with the calculated peptide Vina scores. As outlined earlier, the dipeptide Trp-Val was found to be a non-competitive DPP-IV inhibitor and in agreement with this the peptide was shown to bind to a secondary binding site outside the DPP-IV active site.

Docking analysis predicted that for large peptides, (thirteen to fifty amino acids) derived from tryptic digests of amaranth protein, the mechanism of binding was related to the physicochemical properties of the peptide $^{(56)}$. It was proposed that the neutral peptide (11S amaranth globulin $\mathrm{f}(1-13)$ ) would bind inside the active site blocking access to the natural substrates. While the acidic peptides (11S amaranth globulin $\mathrm{f}(18-39)$, $\mathrm{f}(69-81)$ and $\mathrm{f}(92-143))$ were located at the dimerisation site and blocked formation of the dimeric DPP-IV active form. The interactions between the DPP-IV and amaranth peptides were also principally via hydrophobic interaction and hydrogen bonds. As indicated earlier, peptide inhibition of DPP-IV may therefore involve multiple mechanisms of action. Consequently, an effective combination of both in silico and empirical approaches may advance our understanding and discovery of those structural features essential for potent DPP-IV inhibitory peptides.

\section{In vivo animal studies}

To date, only a small number of animal studies have evaluated the efficacy of DPP-IV inhibitory hydrolysates or peptides. The gluco-regulatory effect of a tryptic digest of $\beta-\mathrm{Lg}$ was evaluated in vivo using mice ${ }^{(64)}$. Animals received the control (Tris- $\mathrm{HCl}$ buffer), $\beta$-Lg hydrolysate $(300 \mathrm{mg} / \mathrm{kg})$ or Sitagliptin phosphate hydrate $(3 \mathrm{mg} / \mathrm{kg})$ $30 \mathrm{~min}$ prior to an oral glucose tolerance test. Over the $2 \mathrm{~h}$ post-prandial period, the $\beta$-Lg hydrolysate decreased plasma glucose concentrations approximately $14 \%$ relative to the control. However, it was not as effective as Sitagliptin, the drug inhibitor of DPP-IV, which produced a $27 \%$ reduction in plasma glucose relative to the control. A peptide (Leu-Pro-Gln-Asn-Ile-ProPro-Leu) derived from Gouda-type cheese which has shown DPP-IV inhibitory activity in vitro was further evaluated in vivo in rats ${ }^{(63)}$. The peptide was administered $(300 \mathrm{mg} / \mathrm{kg})$ as part of an oral glucose tolerance test $(60 \mathrm{mg} / \mathrm{ml})$. During the $2 \mathrm{~h}$ post-prandial period, administration of the peptide reduced plasma glucose by approximately $30 \%$ relative to the control.

The Zucker, diabetic, fatty rat model of T2DM was used to evaluate the in vivo bioactivity of an egg lysozyme hydrolysate $^{(69)}$. The hydrolysate and positive control, Vildagliptin, were administered by oral gavage and were evaluated over a $6 \mathrm{~h}$ period. The hydrolysate resulted in $25 \%$ inhibition of plasma DPP-IV after 90 min and the time-course of the response was similar to that of Vildagliptin. However, changes in the incretin hormone levels and glycaemic responses were not reported. A previous study in Zucker rats reported that 20-30\% inhibition of plasma DPP-IV activity was sufficient to increase active GLP-1 and reduce hyperglycaemia during an oral glucose tolerance test ${ }^{(79)}$. Therefore, it may be anticipated that the level of inhibition reported for the egg lysozyme hydrolysate might induce a similar response.

A zein protein hydrolysate (ZeinH) has been shown to increase GLP-1 secretion in mice ${ }^{(24)}$. This activity was investigated further in rats ${ }^{(80)}$. The ZeinH $(500 \mathrm{mg})$ had glucoregulatory activity when administered prior to an intraperitoneal glucose $(1 \mathrm{~g} / \mathrm{kg})$ tolerance test. Administration of the ZeinH resulted in a 2.4-fold increase in peak plasma insulin and a $23 \%$ decrease in peak plasma glucose relative to the control (meat hydrolysate). In addition, the incretin effect was also evaluated by the changes in total and active GLP-1. The ZeinH increased active GLP1 (approximately threefold within $15 \mathrm{~min})$ relative to the control. Changes in active GLP-1 were correlated with changes in plasma insulin and glucose. Finally, administration of the ZeinH was 
found to decrease plasma DPP-IV activity by $20-26 \%$ from basal levels and these concentrations were significantly lower than the control. This highlights the potential multi-functionality (induction of GLP-1 secretion and decrease in plasma DPP-IV activity) of the ZeinH which resulted in enhanced insulin secretion and attenuated hyperglycaemia.

The data discussed highlight the potential of foodderived peptides in the management of T2DM. However, more detailed human studies are required to fully evaluate efficacy, safety and potency. In particular, there is a need for human studies to evaluate milk protein-derived DPP-IV inhibitors.

\section{Management of type 2 diabetes}

The therapeutic application of GLP-1 for the management of T2DM was first evaluated in the early 1990s. At that time, GLP-1 differed from other antidiabetic agents because the insulinotropic action was stimulated by nutrient ingestion therefore reducing the risk of hypoglycaemia. This led to the development of pharmacological compounds that targeted the incretin axis and, in particular, those that enhanced GLP-1 secretion or increased GLP-1 half-life. As outlined earlier, DPP-IV is a primary regulator of incretin hormone activity and this has led to a focus on the use of DPP-IV inhibitors as a therapeutic strategy.

Synthetic drug inhibitors of DPP-IV have been shown to lower blood glucose and to prevent inactivation of GLP-1 and GIP in healthy adults ${ }^{(81,82)}$ and in T2DM patients ${ }^{(43)}$. In addition, acute ingestion of drug inhibitors (metformin) in $\mathrm{T} 2 \mathrm{DM}$ subjects reduced plasma DPP-IV activity for up to $6 \mathrm{~h}^{(83)}$. Food protein-derived peptide inhibitors of DPP-IV are yet to be fully evaluated in vivo. There is some pre-clinical and clinical evidence that milk protein and milk protein hydrolysates stimulate incretin hormone secretion, display insulinotropic activity and regulate blood glucose in healthy and diabetic populations ${ }^{(10,84-86)}$. However, the effect of protein hydrolysates on plasma DPP-IV activity in human subjects is yet to be evaluated.

Food protein-derived peptide inhibitors of DPP-IV identified to date have not shown equivalent potency to synthetic drug inhibitors. Therefore, these inhibitors may be most suited to combination therapy or as part of a nutritional intervention strategy in pre-diabetic or mild diabetic patients. Peptide-drug interactions of DPP-IV inhibitors have been evaluated in vitro ${ }^{(87)}$. These combination studies were conducted using the synthetic drug inhibitor of DPP-IV, Sitagliptin, with either a WP-derived hydrolysate or dipeptides (Trp-Val and Val-Ala) with DPP-IV inhibitory activity. These studies showed that there was an additive effect of Sitagliptin and the milk-derived peptides on DPP-IV inhibition. This highlights the potential for combination (food and drug) therapy, which may be used in the management of T2DM.

If the DPP-IV inhibitory activity demonstrated in vitro is to translate in vivo then the bioavailability of the peptides must also be established. Some DPP-IV peptide inhibitors identified earlier have shown other biofunctionalities in vivo. The peptide Ile-Pro-Ala has also shown antihypertensive properties following oral ingestion in rats ${ }^{(75)}$. The efficacy and potency of DPP-IV inhibitory peptides in human subjects remains to be established.

\section{Conclusions}

The importance and scientific understanding of DPP-IV activity within incretin hormone biology has increased rapidly in the last 20 years. Inhibitors of DPP-IV are now an established therapeutic approach for the treatment of T2DM. However, synthetic drug inhibitors are not without their limitations and side-effects. Therefore, there is a growing interest in natural, food-derived peptide inhibitors as these may be effective without displaying undesirable side-effects. Much in vitro and some in vivo works have highlighted the potential of foodderived peptides as effective DPP-IV inhibitors. Some food-derived peptide inhibitors have demonstrated potential to decrease plasma DPP-IV activity, inhibit degradation of incretin hormones and maintain glucose homoeostasis in small animals. If the scientific understanding and clinical efficacy of these compounds is further advanced they may offer a unique biofunctional-peptide-based nutritional strategy for use in the management of T2DM.

\section{Acknowledgements}

None.

\section{Financial support}

The work described here was supported by Enterprise Ireland under grant number CC20080001.

Enterprise Ireland had no role in the design, analysis or writing of this article.

\section{Conflicts of interest}

None.

\section{Authorship}

O. P. had primary responsibility for writing the manuscript R. J. F., P. J. and A. B. N. critically revised the manuscript. All the authors read and approved the final submission.

\section{References}

1. World Health Organisation (2012) Diabetes programme, country and regional data. http://www.who.int/diabetes/ facts/world_figures/en/ (accessed 12 September 2012). 
2. Ben-Avraham S, Harman-Boehm I, Schwarzfuchs D et al. (2009) Dietary strategies for patients with type 2 diabetes in the era of multi-approaches; review and results from the dietary intervention randomized controlled trial (DIRECT). Diabetes Res Clin Pract 86, S41-S48.

3. Drucker DJ (2006) The biology of incretin hormones. Cell Metab 3, 153-165.

4. Drucker DJ (2007) Dipeptidyl peptidase-4 inhibition and the treatment of type 2 diabetes. Diabetes Care 30, 1335-1343.

5. Gupta V \& Kalra S (2011) Choosing a gliptin. Indian J Endo Metab 15, 298-308.

6. Krushner P \& Gorrell M (2010) DPP-4 inhibitors in type 2 diabetes: importance of selective enzyme inhibition and implications for clinical use. J Fam Pract 59, 2.

7. American Diabetes Association (2009) Standards of medical care in diabetes-2009. Diabetes Care 32, S13-S61.

8. FitzGerald RJ \& Meisel H (2003) Milk protein hydrolysates and bioactive peptides. In Advanced Dairy Chemistry 1: Proteins, 3rd ed., pp. 675-698 [PF Fox \& PLH Mc Sweeney, editors]. New York: Kluwer Academic/Plenum Publishers.

9. Murray BA \& FitzGerald RJ (2007) Angiotensin converting enzyme inhibitory peptides derived from food proteins: biochemistry, bioactivity and production. Curr Pharm Des 13, 773-791

10. Frid AH, Nilsson M, Holst JJ et al. (2005) Effect of whey on blood glucose and insulin responses to composite breakfast and lunch meals in type 2 diabetic subjects. Am J Clin Nutr 82, 69-75.

11. Manders RJF, Wagenmakers AJM, Koopman R et al. (2005) Co-ingestion of a protein hydrolysate and amino acid mixture with carbohydrate improves plasma glucose disposal in patients with type 2 diabetes. Am J Clin Nutr 82, 76-83.

12. Lacroix IME \& Li-Chan ECY (2012) Dipeptidyl peptidase-IV inhibitory activity of dairy protein hydrolysates. Int Dairy J 25, 97-102.

13. Nongonierma AB \& FitzGerald RJ (2013a) Dipeptidyl peptidase IV inhibitory and antioxidative properties of milk protein-derived dipeptides and hydrolysates. Peptides 39, 157-163.

14. Perley MJ \& Kipnis DM (1967) Plasma insulin responses to oral and intravenous glucose: studies in normal and diabetic subjects. J Clin Invest 46, 1954-1962.

15. Nauck M, Homberger E, Siegel EG et al. (1986) Incretin effects of increasing glucose loads in man calculated from venous insulin and C-peptide responses. J Clin Endocr Metab 63, 492-498.

16. Kim W \& Egan JM (2008) The role of incretins in glucose homeostasis and diabetes treatment. Pharmacol Rev 60, $470-512$.

17. Nauck M, Stöckmann F, Ebert R et al. (1986) Reduced incretin effect in type 2 (non-insulin-dependent) diabetes. Diabetologia 29, 46-52.

18. Vilsbøll T, Krarup T, Deacon CF et al. (2001) Reduced postprandial concentrations of intact biologically active glucagon-like peptide 1 in type 2 diabetic patients. Diabetes 50, 609-613.

19. Nauck MA, Bartels E, Orskov C et al. (1993) Additive insulinotropic effects of exogenous synthetic human gastric inhibitory polypeptide and glucagon-like peptide-1-(7-36) amide infused at near-physiological insulinotropic hormone and glucose concentrations. J Clin Endocr Metab 76, 912-917.

20. Drucker D (2003) Therapeutic potential of dipeptidyl peptidase IV inhibitors for the treatment of type 2 diabetes. Expert Opin Inv Drug 12, 87-100.
21. Reimann F, Habib AM, Tolhurst G et al. (2008) Glucose sensing in L cells: a primary cell study. Cell Metab 8 , 532-539.

22. Hall WL, Millward DJ, Long SJ et al. (2003) Casein and whey exert different effects on plasma amino acid profiles, gastrointestinal hormone secretion and appetite. $\mathrm{Br} J$ Nutr 89, 239-248.

23. Power O, Conway C, McCormack W et al. (2011) A comparison of the insulinotropic and enterogastric response to ingestion of an equivalent quantity of maltodextran and whey protein. Proc Nutr Soc 70, E357.

24. Hira T, Mochida T, Miyashita K et al. (2009) GLP-1 secretion is enhanced directly in the ileum but indirectly in the duodenum by a newly identified potent stimulator, zein hydrolysate, in rats. Am J Physiol Gastrointest Liver Physiol 297, G663-G671.

25. Oya M, Kitaguchi T, Pais R et al. (2012) The GPRC6A receptor is involved in amino acid-induced glucagon-like peptide-1 secretion from GLUTag cells. J Biol Chem 288, 4513-4521.

26. Reimann F, Williams L, Silva Xavier G et al. (2004) Glutamine potently stimulates glucagon-like peptide-1 secretion from GLUTag cells. Diabetologia 47, 1592-1601.

27. Lindgren O, Carr RD, Deacon CF et al. (2011) Incretin hormone and insulin responses to oral versus intravenous lipid administration in humans. J Clin Endocr Metab 96, 2519-2524.

28. Schirra J, Katschinski M, Weidmann C et al. (1996) Gastric emptying and release of incretin hormones after glucose ingestion in humans. $J$ Clin Invest 97, 92-103.

29. Mentlein R, Gallwitz B \& Schmidt WE (1993) Dipeptidyl-peptidase IV hydrolyses gastric inhibitory polypeptide, glucagon-like peptide-1(7-36) amide, peptide histidine methionine and is responsible for their degradation in human serum. Eur J Biochem 214, 829-835.

30. Holst JJ (2007) The physiology of glucagon-like peptide 1 . Physiol Rev 87, 1409-1439.

31. Kreymann B, Ghatei MA, Williams G et al. (1987) Glucagon-like peptide 1 7-36: a physiological incretin in man. Lancet 330, 1300-1304.

32. Wettergren A, Schjoldager B, Mortensen PE et al. (1993) Truncated GLP-1 (proglucagon 78-107-amide) inhibits gastric and pancreatic functions in man. Digest Dis Sci 38, 665-673.

33. Näslund E, Bogefors J, Skogar S et al. (1999) GLP-1 slows solid gastric emptying and inhibits insulin, glucagon, and PYY release in humans. Am J Physiol Regul Integr Comp Physiol 277, R910-R916.

34. Flint A, Raben A, Astrup A et al. (1998) Glucagon-like peptide 1 promotes satiety and suppresses energy intake in humans. $J$ Clin Invest 101, 515-520.

35. Rijkelijkhuizen JM, McQuarrie K, Girman CJ et al. (2010) Effects of meal size and composition on incretin, $\alpha$-cell, and $\beta$-cell responses. Metabolis 59, 502-511.

36. Kim S-J, Nian C \& McIntosh CHS (2007) Activation of lipoprotein lipase by glucose-dependent insulinotropic polypeptide in adipocytes. $J$ Biol Chem 282, 8557-8567.

37. Vilsbøll T, Krarup T, Madsbad S et al. (2003) Both GLP-1 and GIP are insulinotropic at basal and postprandial glucose levels and contribute nearly equally to the incretin effect of a meal in healthy subjects. Regul Pept 114, 115-121.

38. Holst JJ \& Gromada J (2004) Role of incretin hormones in the regulation of insulin secretion in diabetic and nondiabetic humans. Am J Physiol Endo M 287, E199-E206.

39. Marguet D, Baggio L, Kobayashi T et al. (2000) Enhanced insulin secretion and improved glucose tolerance in mice lacking CD26. Proc Natl Acad Sci USA 97, 6874-6879. 
40. Nagakura T, Yasuda N, Yamazaki K et al. (2003) Enteroinsular axis of $\mathrm{db} / \mathrm{db}$ mice and efficacy of dipeptidyl peptidase IV inhibition. Metabolis 52, 81-86.

41. Conarello SL, Li Z, Ronan J et al. (2003) Mice lacking dipeptidyl peptidase IV are protected against obesity and insulin resistance. Proc Natl Acad Sci USA 100, 6825-6830.

42. Hu P, Yin Q, Deckert F et al. (2009) Pharmacokinetics and pharmacodynamics of vildagliptin in healthy chinese volunteers. J Clin Pharmacol 49, 39-49.

43. Ahrén B, Landin-Olsson M, Jansson P-A et al. (2004) Inhibition of dipeptidyl peptidase-IV reduces glycemia, sustains insulin levels, and reduces glucagon levels in type 2 diabetes. J Clin Endocr Metab 89, 2078-2084.

44. Yu DMT, Yao T-W, Chowdhury S et al. (2010) The dipeptidyl peptidase IV family in cancer and cell biology. FEBS J 277, 1126-1144.

45. Mentlein R (1999) Dipeptidyl-peptidase IV (CD26)-role in the inactivation of regulatory peptides. Regul Pept 85, 9-24.

46. Gorrell MD (2005) Dipeptidyl peptidase IV and related enzymes in cell biology and liver disorders. Clin Sci 108, 277-292.

47. Aertgeerts K, Ye S, Tennant MG et al. (2004) Crystal structure of human dipeptidyl peptidase IV in complex with a decapeptide reveals details on substrate specificity and tetrahedral intermediate formation. Protein Sci 13, 412-421.

48. Rasmussen HB, Branner S, Wiberg FC et al. (2003) Crystal structure of human dipeptidyl peptidase IV/CD26 in complex with a substrate analog. Nat Struct Mol Biol 10, 1925.

49. Kühn-Wache K, Bär JW, Hoffmann T et al. (2011) Selective inhibition of dipeptidyl peptidase 4 by targeting a substrate-specific secondary binding site. Biol Chem 392, 223-231.

50. Lambeir A-M, Durinx C, Scharpé S et al. (2003) Dipeptidyl-Peptidase IV from bench to bedside: an update on structural properties, functions, and clinical aspects of the enzyme DPP IV. Crit Rev Clin Lab Sci 40, 209.

51. Ahrén B, Schweizer A, Dejager S et al. (2011) Mechanisms of action of the dipeptidyl peptidase-4 inhibitor vildagliptin in humans. Diabetes Obes Metab 13, 775-783.

52. Rahfeld J, Schierborn M, Hartrodt B et al. (1991) Are diprotin A (Ile-Pro-Ile) and diprotin B (Val-Pro-Leu) inhibitors or substrates of dipeptidyl peptidase IV? BBA-Protein Struct M 1076, 314-316.

53. Hatanaka T, Inoue Y, Arima J et al. (2012) Production of dipeptidyl peptidase IV inhibitory peptides from defatted rice bran. Food Chem 134, 797-802.

54. Potashman MH \& Duggan ME (2009) Covalent modifiers: an orthogonal approach to drug design. J Med Chem $\mathbf{5 2}$, $1231-1246$

55. Hoffmann T, Kuehn-Wache K, Demuth H-U et al. (2002) inventors; OSI Pharmaceuticals, Inc., assignee. The present application relates to the secondary binding site of dipeptidyl peptidase $I V$, its relationship amongst substrates and to the modulation of substrate specificity of dipeptidyl peptidase $I V$. United States US 2004/0058876 A1 (Patent).

56. Velarde-Salcedo AJ, Barrera-Pacheco A, Lara-González S et al. (2013) In vitro inhibition of dipeptidyl peptidase IV by peptides derived from the hydrolysis of amaranth (Amaranthus hypochondriacus L.) proteins. Food Chem 136, 758-764.

57. Lorey S, Stöckel-Maschek A, Faust J et al. (2003) Different modes of dipeptidyl peptidase IV (CD26) inhibition by oligopeptides derived from the N-terminus of HIV-1 Tat indicate at least two inhibitor binding sites. Eur J Biochem 270 , $2147-2156$
58. Haque E, Chand R \& Kapila S (2009) Biofunctional properties of bioactive peptides of milk origin. Food Revs Int $\mathbf{2 5}$, $28-43$.

59. Korhonen H (2009) Milk-derived bioactive peptides: From science to applications. J Funct Food 1, 177-187.

60. Lacroix IME \& Li-Chan ECY (2012) Evaluation of the potential of dietary proteins as precursors of dipeptidyl peptidase (DPP)-IV inhibitors by an in silico approach. $J$ Funct Food 4, 403-422.

61. Li-Chan ECY, Hunag S-L, Jao C-L et al. (2012) Peptides derived from atlantic salmon skin gelatin as dipeptidylpeptidase IV inhibitors. J Agric Food Chem 60, 973-978.

62. Huang S-L, Jao C-L, Ho K-P et al. (2012) Dipeptidyl-peptidase IV inhibitory activity of peptides derived from tuna cooking juice hydrolysates. Peptides 35, 114-121.

63. Uenishi H, Kabuki T, Seto Y et al. (2012) Isolation and identification of casein-derived dipeptidyl-peptidase 4 (DPP-4)-inhibitory peptide LPQNIPPL from gouda-type cheese and its effect on plasma glucose in rats. Int Dairy $J$ 22, 24-30.

64. Uchida M, Ohshiba Y \& Mogami O (2011) Novel dipeptidyl peptidase-4 inhibiting peptide derived from betalactoglobulin. J Pharmacol Sci 117, 63-66.

65. Tulipano G, Sibilia V, Caroli AM et al. (2011) Whey proteins as source of dipeptidyl dipeptidase IV (dipeptidyl peptidase-4) inhibitors. Peptides 32, 835-838.

66. Silveira ST, Martínez-Maqueda D, Recio I et al. (2013) Dipeptidyl peptidase-IV inhibitory peptides generated by tryptic hydrolysis of a whey protein concentrate rich in $\beta$-lactoglobulin. Food Chem 141, 1072-1077.

67. Tominaga Y, Yokota S, Tanaka H et al. (2012) inventors; Kaneka Corporation, assignee. Dipeptidyl peptidase-4 inhibitor. United States US 20120189611 (Patent).

68. Silva-Sánchez C, de la Rosa APB, León-Galván MF et al. (2008) Bioactive peptides in amaranth (Amaranthus hypochondriacus) seed. J Agric Food Chem 56, 1233-1240.

69. Aart V, Catharina M, Zeeland-Wolbers V et al. (2009) inventors; Newtricous B.V., assignee. Egg protein hydrolysates. WO 2009/128713 (Patent).

70. Foltz M, Van Buren L, Klaffke W et al. (2009) Modeling of the relationship between dipeptide structure and dipeptide stability, permeability, and ACE inhibitory activity. $J$ Food Sci 74, H243-H251.

71. Nongonierma AB, Mooney C, Shields DC et al. (2013b) Inhibition of dipeptidyl peptidase IV and xanthine oxidase by amino acids and dipeptides. Food Chem 141, 644-653.

72. Fox P, McSweeney P (2003) Proteins. In Advanced Dairy Chemistry, 3rd ed., pp. 146-238 [P Fox \& P McSweeney, editors]. New York: Kluwer Academic/Plenum Publishers.

73. Boots J (2006) inventor Campina Nederland Holding B.V., assignee. Protein hydrolysates enriched in peptides inhibiting DPP IV and thier use. WO 2006/068480 200 (Patent).

74. Maritim AC, Sanders RA \& Watkins JB (2003) Diabetes, oxidative stress, and antioxidants: a review. J Biochem Mol Toxic 17, 24-38.

75. Abubakar A, Saito T, Kitazawa H et al. (1998) Structural analysis of new antihypertensive peptides derived from cheese whey protein by proteinase $\mathrm{K}$ digestion. J Diary Sci 81, 3131-3138.

76. Durrant J \& McCammon JA (2011) Molecular dynamics simulations and drug discovery. BMC Bio 9,71 .

77. Pripp A (2007) Docking and virtual screening of ACE inhibitory dipeptides. Eur Food Res Technol 225, 589-592.

78. Norris R, Casey F, FitzGerald RJ et al. (2012) Predictive modelling of angiotensin converting enzyme inhibitory dipeptides. Food Chem 133, 1349-1354. 
79. Tanaka-Amino $\mathrm{K}$, Matsumoto $\mathrm{K}$, Hatakeyama $\mathrm{Y}$ et al. (2008) ASP4000, a novel, selective, dipeptidyl peptidase 4 inhibitor with antihyperglycemic activity. Eur $J$ Pharmacol 590, $444-449$.

80. Mochida T, Hira T \& Hara H (2010) The corn protein, zein hydrolysate, administered into the ileum attenuates hyperglycemia via its dual action on glucagon-like peptide-1 secretion and dipeptidyl peptidase-IV activity in rats. Endocrinology 151, 3095-3104.

81. Ahrén B, Simonsson E, Larsson H et al. (2002) Inhibition of dipeptidyl peptidase IV improves metabolic control over a 4 -week study period in type 2 diabetes. Diabetes Care $\mathbf{2 5}$, 869-875.

82. Ahrén B, Gomis R, Standl E et al. (2004) Twelve- and 52-week efficacy of the dipeptidyl peptidase IV Inhibitor LAF237 in metformin-treated patients with type 2 diabetes. Diabetes Care 27, 2874-2880.

83. Lindsay JR, Duffy NA, McKillop AM et al. (2005) Inhibition of dipeptidyl peptidase IV activity by oral metformin in Type 2 diabetes. Diabetic Med 22, 654 657.

84. Nilsson M, Holst JJ \& Bjorck IME (2007) Metabolic effects of amino acid mixtures and whey protein in healthy subjects: studies using glucose-equivalent drinks. Am J Clin Nutr 85, 996-1004.

85. Power O, Hallihan A \& Jakeman P (2009) Human insulinotropic response to oral ingestion of native and hydrolysed whey protein. Amino Acids 37, 333339.

86. van Loon L, Saris W, Verhagen H et al. (2000) Plasma insulin response after ingestion of different amino acid or protein mixtures with carbohydrate. Am J Clin Nutr 72, 96-105.

87. Nongonierma AB \& FitzGerald RJ (2013c) Dipeptidyl peptidase IV inhibitory properties of a whey protein hydrolysate: influence of fractionation, stability to simulated gastrointestinal digestion and food-drug interaction. Int Dairy J 32, 33-39. 